\title{
SOME SELECTED FACTORS OF SUCCESS OF ENTERPRISES. THEORY AND PRACTICE
}

\author{
Lech NIEŻURAWSKI ${ }^{1}$, Joanna NIEŻURAWSKA-ZAJĄC ${ }^{2 *}$ \\ ${ }^{1}$ WSB University in Toruń, Poland; lech.niezurawski@torun.wsb.pl, ORCID: 0000-0001-6396-3363 \\ ${ }^{2}$ WSB University in Torun, Poland; joanna.niezurawska@torun.wsb.pl, ORCID: 0000-0001-6353-1085 \\ * Correspondence author
}

Purpose: The aim of the present article is to show the possibility of using some selected methods of strategic analysis in diagnosing the developmental processes of the enterprise.

Design/methodology/approach: The method of case study was used here to describe the road to success of some selected enterprises: Nike, a Polish company - Inglot and a Swiss enterprise Breitling.

Practical implications: Internationalisation is becoming part of strategy of a growing number of firms which have to put an enormous effort in its success.

Findings: The conclusion is that success is an extremely complex process. It is not possible to determine a concrete list of factors which will help us certainly achieve it, but the examination of the factors and their analysis will make it possible to observe certain regularities which will be very helpful for enterprises.

Social implications: Mission, vision, strategy, strategic analyses, all those elements undeniably bring men of action nearer to success. However, we shouldn't limit ourselves to them; rather, giving all of ourselves, all our knowledge and commitment, we should reach for success with our own hands.

Originality/value: The article presents known methods: SWOT Analysis and the Key Success Factors (KSF). They are popular and the most commonly applied methods in enterprises. The value of the paper is based on their appropriate use in order to contribute to the firm's success.

Keywords: factors of success of enterprises, strategic analyses, case study, SWOT, Key Success Factors (KSF).

Category of the paper: case study ${ }^{1}$.

\footnotetext{
${ }^{1}$ Case study. Case studies describe actual interventions or experiences within organizations. They may be subjective and would not generally report on research. A description of a legal case or a hypothetical case study used as a teaching exercise would also fit into this category.
} 


\section{Introduction}

There is no golden recipe for success and it frequently happens that even the firms which have, it would seem, a foolproof strategy - go bankrupt. However, the realisation of proper strategies considerably helps in conducting business activity. Risk is an inevitable companion of firms' leaders. It is the managers who often have to make the decisions which weigh on the future of their firms. Sometimes they are correct decisions and bring the expected profits or even exceed them, but sometimes they end in a complete disaster or even bankruptcy of the enterprise.

There exist numerous methods which bring firms nearer to achieving success. A number of strategies have been elaborated on and numerous scientists have devoted a great deal of their time in order to determine the actual mechanism of achieving success on the market. However, history teaches us that application of identical procedures at two different time moments leads to completely different outcomes.

There are no accurately defined instructions or strategies whose application would guarantee the achievement of success. However, it can be undoubtedly claimed that a firm which has achieved success, has conquered the market. A growing number of new suggestions are being formulated for the firms which desire to succeed. It is not, however, such a simple matter, as there is an infinite number of factors which are involved in success. Their in-depth analysis might help hierarchise them and their adequate combination - create a 'success strategy' for the enterprise. Alas, there is no golden means for success and it frequently happens that even the firms which have, it would seem, a foolproof strategy - go bankrupt. Nevertheless, the realisation of appropriate strategies considerably helps conduct business activity. Risk is an integral companion of firms' leaders. It is the managers who often have to make decisions which weigh on the future of their firms. Sometimes they are correct and bring the expected profits or even exceed them, but sometimes they end in a complete disaster or even lead to the bankruptcy of the enterprise.

The aim of the present study is to show that it is impossible to clearly determine the particular factors conditioning the success of an enterprise on the market. Nevertheless, once a firm has already achieved it, the elements which have determined that competitive advantage can be searched out.

The following methods have been used in this study: the method of description and of comparative analysis, some elements of the SWOT and of the Key Success Factors (KSF) methods, and case study. 


\section{The gist and the factors conditioning a success of the enterprise}

The firm's success or failure is the consequence of the adjustment of its capabilities to the challenges involved. We must be aware of the fact that there are no ready-made recipes or strategies which bring success. They can't exist as it would mean eliminating all kinds of competitive advantage. The basis of success of a given firm is specific to this and only to this firm. Many factors are involved in its success. They may be, for instance, its relationships with the stakeholders, who very often include in their ranks investors, clients, suppliers, employees, managers, trade unions, and the state. An effective firm shapes these relations in such a way that it will maximise its profits.

Success factors (SF) are hierarchised by firms and considered individually by each of them. Some factors have more significance for certain enterprises, some other for other enterprises. In fact, the notion of a firm's success is very wide (Cardwell, Geoff, 2008). Some entrepreneurs stress the size and the market share, some other - profitability and the advantages achieved by the shareholders. Some speak of technical efficiency and ability to implement innovations while others appreciate the reputation the enterprise has with its customers, employees and in business circles.

Evidently, the notion of success has not been very clearly defined. And it is not surprising, since success is not a single outcome but a process. We can speak of a given company's success only in retrospect. What is success today, may not be so any more on the following day.

Why do only few businesses among those starting on the market from a similar position and with a comparable supply of resources achieve authentic success, while others become only the (necessary) background in the industry, with the majority having fatal prospects and most frequently disappearing almost unnoticed? Research workers and experts have been trying to answer this question for many years. Accounting for the causes of firms' successes and failures, however, is not simple (Hoffmann et al., 2001).

Success is a very complex process and nobody can create a unequivocal formula to achieve it. However, through an insightful analysis we can distinguish certain factors which are undisputedly involved in it. Companies carry out a hierarchisation of their objectives, which may be the following (Pierścionek, 2003):

- a specified sales growth rate in the particular groups of products and the total growth rate,

- maintenance of the market share in a given market (markets),

- a particular increase of market share in the particular markets (at a given time),

- attainment of the position of market leader or the domineering position on the market,

- entering a new market (markets), home or overseas,

- diversification of markets, 
- maintenance of the current profitability level or its particular increase over a specified period of time to the average in the industry,

- attainment of the position of industry leader.

Success is determined not so much by the volume of the owned capital as by the ability to create a certain idea or find an idea to create a firm, the ability to create a certain vision and transform it into a particular mission or strategy (Islam, Md Aminul, et al., 2011).

When selecting a proper strategy for the firm out of many options, the firm's priority must be specified. The following three main criteria should be the basis of strategy selection:

- input, i.e. all the information related to the firm's surroundings and in particular to the power of competition, and the internal information, i.e. the firm's strong and weak points, production capability, resources owned and the like,

- the expected changes, all the changes pertaining to the firm's further development and its future e.g. the changes in the requirements concerning environment protection, in costs levels, in the internal structure of the organisation, in the assortment, or similar,

- the intended achievements such as e.g. winning new markets, increasing profitability, increasing the volume of the turnovers, or similar.

The success of a strategy depends on many factors, but the key factor is the choice of a particular variant and its implementation. There is, however, no universal method of choice of the strategy which will in all certainty bring success to the firm. Strategies are not objectively optimal and application of ready-made patterns may not bring the expected effects. All pros and cons should be carefully analysed and only then should the choice of a strategy be made. Customer satisfaction should be monitored all the time, as it may provide the measure of the strategy's effectiveness. It is important not to dissociate oneself from the constantly changing market, and the market research may help the firm build permanent success.

Strategy is the most important element in the management process, the outcome of the combination of the vision, mission, objectives and tasks of the enterprise. In order to create a strategy which will lead to success, actions aiming at elimination of uncertainty should be taken and such a project must be created which will fully specify the assumed aims and the paths of their realisation. Strategy is also often treated as the firm's secret, since it is not in its best interest for the competition to get to know it (Nieżurawski, Owczarczyk-Szpakowska, 2005, p. 35).

\section{Methods useful in formulating of the enterprise's strategy}

In order to elaborate on a proper strategy one must acquaint oneself with both the surroundings and the enterprise itself, identify the possible future changes in the surroundings and adjust the firm's reaction to these putative changes. It is exactly what strategic analysis 
offers. It is a complex of actions and methods which diagnose the company and its surroundings, make it possible to assess its current condition, prognose its future operations and on their basis elaborate on the appropriate strategies. The notion of analysis is understood in a very wide sense: "not only as a set of methods and procedural stages but also as a mode of operation characterising people and organisations who think in terms of strategies". And to think in terms of strategies means the following (Porter, 2008):

- undertake the efforts to take the cognisance of the current situation, study the opportunities, select the objectives, tasks and principles, use the resources and think many years ahead,

- use a complex of techniques and methods of analysis and synthesis, thus making realisation of those efforts and collection of the indispensable information possible,

- have the will to constantly change the areas and the methods of area change as well as the manner of the company's operation, in harmony with the changes in its vision and surroundings.

Strategic analysis must be adjusted to the current situation of the enterprise and it depends among others on its size, the sector in which it operates, the market life cycle of its products, the power of the competition, its organisational structure, the technologies applied therein, the manner of management, or similar.

Strategic analysis of an enterprise is a very wide notion. Depending on individual preferences, enterprises select the method of strategic analysis which they consider appropriate for them in order to further pursue the desired success: to prevent being removed from the market or appear on a new one, or extend the operation to the remaining regions or sectors. Apparently, there are numerous factors which can help achieve success or, on the contrary, inhibit the enterprise's development. That is why a properly prepared and conducted analysis is indispensable in every business. Provided it is appropriately conducted, it allows to predict the firm's future. Admittedly, it gives a somewhat blurred image and one the that couldn't give us the certainty of success; nevertheless, it makes it possible for us to be ready for the continual changes taking place in economy. "Hence, the strategic analysis allows to define the strategic position of the company due to the juxtaposition of the opportunities and threats coming from its surroundings on the one hand, and on the other - of its weaknesses and strengths resulting from the internal shape of the company's potential" (Grant, 2016).

Below, two methods of strategic analysis have been presented synthetically, i.e. the SWOT method and the KSF method. They are very popular methods which are supposed to indicate to enterprises the path to success. Now, is it certain that an adequately performed analysis is sufficient in itself? In order to judge this, one must take a closer look at them. 


\section{SWOT Analysis}

SWOT analysis is one of the traditional concepts of strategic management and consists in an analysis of the strengths and weaknesses of an enterprise in the conditions of opportunities and dangers created by the surroundings. The name 'SWOT' is the acronym of the following English words: strengths (strong points), weaknesses (weak points), opportunities (chances) and threats (dangers) (Pickton, 1998).

SWOT analysis involves both external and internal analysis. External analysis, i.e. opportunities and dangers, is the analysis of all the factors influencing the firm's operation which come from the outside, from beyond the area of its operation, and over which it has no control. Internal analysis, i.e. strengths and weaknesses, is in turn the analysis of the current firm's potential and of its developmental opportunities.

External analysis should include such areas of the external surroundings as the following (Valentin, 2001):

- socio-cultural areas,

- legal,

- political,

- demographic,

- technical-technological,

- economic,

- physical and the like.

In this analysis the following factors among others should be taken into account and evaluated: law, customs regulations, taxes, technological advances and probably the most important one i.e. the competition. The situation in the surroundings of the enterprise is constantly changing. The ongoing events may create new possibilities; there may appear new impulses to undertake risks and activate production marketing operations. However, the turn of events may be such that the business activity conducted so far may turn out unprofitable. Apparently, these factors may bring both opportunities and threats. Opportunities may be defined as the tendencies and phenomena in the firm's surroundings which, if properly taken advantage of, may become stimuli for its growth and help alleviate the existing difficulties, whereas threats are all the external factors which are perceived as barriers, obstacles, additional operational costs, or dangers.

Internal analysis aims at an identification and evaluation of the material and non-material factors which favour or inhibit the company's growth both at present and in the future. Its objectives are the following:

- indicating these elements in the company's resources which may be treated as its undoubtable strengths (special values differing it from its competitors) in the clash with potential competitors on the market, 
- disclosure of putatively weak areas (limitations), decreasing the force of business's own competitive impact and, at the same time, creating an opportunity for an effective attack on the part of the competition,

- defining the particular predispositions of the enterprise to realise its objectives in the complex market area, including the interdependencies between the particular elements and their significance in the whole set of tools of influencing the market.

In internal analysis, the most important instruments of the company's operation must be taken into account. G. Lancaster and L. Massingham present four groups of such instruments (Lancaster, Massingham, 2010).

1. marketing instruments, i.e. trademarks, the firm's image, distribution, the firm's product's rank, prices, sales opportunities, marketing systems,

2. financial instruments, e.g. capital cost, financial liquidity, profitability, the structure of assets, the price-incomes ratio,

3. production instruments, i.e. generating capacity, equipment age (degree of modernity), production, quality control, economics of scale,

4. personal instruments, i.e. staff's qualifications, adaptability, the intended labour force, industrial relations, the working conditions.

SWOT analysis is not a very complicated method and yet it is still relatively complex. The juxtaposition of opportunities and threats against the strong and weak points of the firm allows to define fairly accurately its position against the background of other firms. It helps formulate the goals of future actions and identify the strategic variants.

When analysing opportunities and threats in sufficient advance, we gain time, which is indispensable to make the due preparations, for instance in the area of labour resources or technology, or to introduce a new product, enter a new market or quit an unprofitable market segment, or the similar (Pahl, Nadine, Richter, 2007).

Irrespectively of the approach taken, wide or narrow, the SWOT analysis has some undeniable advantages. First of all, it is the most comprehensive method of analysis, since it presents all the factors describing the developmental opportunities of an enterprise in one matrix. At the same time, it focuses attention on the most significant strategic factors from each of the four groups. It is a universal tool. Depending on the degree of knowledgeability of the persons using it and on the needs, SWOT analysis may be both a very simple tool and a very complex one if, when filling in the matrix, we will be using a set of complex and precise techniques of analysis. SWOT analysis allows to move easily from the stage of strategic analysis to the stage of strategic planning. The pattern of SWOT analysis helps us observe both the strengths and weaknesses of the enterprise and in its environment we can perceive both the threats and the developmental opportunities. Another advantage of SWOT is the differentiation it makes between the factors which the firm can influence and on which it should concentrate its attention, and the independent factors, also very important for the enterprise, but which it cannot influence and still they have to be taken into account when planning the strategy. 


\section{Analysis of the Key Success Factors (KSFs)}

The method of analysis of strong and weak points using the set of key success factors is a method of analysis of the enterprise's resources and capabilities and an alternative way of making up the strategic balance. The above approach consists in limiting the research to the group of criteria which we consider crucial, decisive as far as the competitive standing and the developmental opportunities of the enterprise are concerned. This group of criteria is called key success factors (KSFs) (De Vasconcellos, E. Sá, Jorge Alberto Sousa, Donald C. Hambrick, 1989).

The so-called Pareto '80-20' principle has given a start to this method. It assumes that in an organisation only $20 \%$ of events decide about $80 \%$ of effects and vice versa - the remaining $80 \%$ of events influence $20 \%$ of the other effects (Reh, 2005). It clearly follows from this principle that not all the factors involved in the firm's success should be studied, but only those $20 \%$ which are responsible for its success or failure, and that only the latter should be analysed in detail. It is a simplified assumption, as the proportions of these factors may be different in the reality of a particular enterprise. However, the error connected with using the KSF method in the evaluation of the firm's potential cannot be significant. The correct analysis and its quality depends on an adequate selection of the factors which fulfill the strategic functions in a given sector.

Economic sectors differ from each other with respect to the list of key success factors. The above list is, therefore, one of each sector's properties and, at the same time, the answer to the following question: "On what factors does the enterprise's success depend in a given sector?" The sector leader meets the criteria included in the list of key success factors to the greatest extent.

The establishment of the list of key success factors in the sectors characterised by a small degree of differentiation of products and a uniform customer structure is not too difficult. However, in the situation where an international market is involved, one which has many customer segments, the task of establishment of these factors gets complicated. Separate lists of key success factors must be elaborated on for the different segments of the sector.

The list of key success factors contains the criteria which are the most important but not sufficient to help gain a competitive advantage and it indicates in which areas and on which problems the enterprise should focus its attention. Competitive strategy consists in the choice of one or several key success factors, their improvement and gaining a competitive advantage in this manner (Thompson, Stricklan, 1996, p. 83). The list containing the key success factors for a given sector may have several or a dozen or so entries. A correct performance of the analysis of strategic standing of an enterprise requires using one of the following methods: 
- conducting a two-stage analysis, with the first stage being the analysis of the enterprise according to the full list of criteria evaluating the firm's condition in all its areas of operation and making on that basis a list of its weak and strong points; the second stage consists in focusing on the key success factors and subjecting them to an insightful analysis;

- limiting the analysis only to the list of key success factors, on condition that the list will be relatively complete, i.e. it will take into account the most important factors from the main areas of the firm's activity.

It is indispensable to create a list of factors characteristic for a given sector so that the strategic analysis may be conducted correctly on the basis of the method of key success factors. It should include such elements as (Grunert et. al., 1992):

1. market position - presented for instance in the form of the firm's market share in per cent,

2. item cost - measured using the value of a unit cost, the ratio of the fixed costs to the variable costs, the cost structure, or the similar,

3. the firm's image and its presence on the market - it examines market customer behaviour, their opinions concerning the product and the firm itself. Market research is the source of information,

4. technical skills and the level of technology - indirect evaluation through the evaluation of the quality of the firm's products, its technical capabilities and the working culture of the staff, the competitiveness of the technology used in production, or the similar,

5. profitability and financial potential - complex methods of financial analysis, portfolio methods and an analysis of each product's life cycle are used,

6. organisational and managerial level-measured using various indices, e.g. defining the labour discipline and performance, the quality of the realised strategies, information system efficiency, or the similar.

Carrying out a proper strategic analysis of the enterprise using the method of key success factors encounters numerous difficulties on its way. The difficulty in establishing a precise list of key success factors has already been mentioned. The establishment of the point of reference and the time perspective from which the condition of the company's development should be examined is another problem (Akkermans et al., 2002).

The majority of specialists in the field of strategic analysis believe that an evaluation of strengths and weaknesses should be performed by a team of consultants composed of the following members: the executive staff and specialists from the enterprise under evaluation and external consultants (Umble et al., 2003).

The evaluation of a given enterprise with respect to its competitors or a strategic group may also be assumed as a reference point in the evaluation of this enterprise. Such an evaluation will be relative; however, it will not allow to establish objectively the standing of the enterprise and its developmental opportunities since the outcome of the evaluation depends on who we are 
comparing ourselves with. That is why also from the methodological point of view it is more appropriate to compare a firm with an ideal profile of key success factors. This method is more objective, for examining all the enterprises from a given sector, we are capable of making a ranking list and clearly establish the best and the worst functioning enterprise and the standing of the firm under study against the background.

Another methodological problem which can be encountered when using the method of key success factors is posed by the time perspective. The KSF method may only serve as a diagnostic tool or when carrying out changes in the strategic position of a given firm, and in this case the prognosis time depends on the future which we predict and for which we create the strategy of the enterprise. The point method of the KSF is the method usually basing on small teams work. It consists of the following stages:

- making a list of KSFs for the sector under examination,

- defining the weights of the particular success factors in question,

- finding out whether in the analysed enterprise each of the key success factors is a weak or a strong point and expressing this rating in terms of numbers,

- comparison of the sum of the weighed ratings for the given firm with the maximum ratings and (or) with the ratings of the other enterprises from the strategic group or sector.

In order for the analysis - performed using the point method of key success factors - to be objective and accurate, the so-called operationalisation of each factor must be performed, i.e. before we enter the phase of evaluation, it must be established in what conditions a given factor will be scored 1, 2, 3, 4 or 5 points. For example, if one of the success factors is a low unit cost, then we assume that the cost leader will get the highest score, the firm characterised by the highest unit costs - the lowest, and the enterprise whose unit cost oscillates around the sector average - an average score (3 points).

The SWOT method and the method of key success factors rank as the most popular methods of strategic analysis of 'ourselves' and of our competitors. It is very important for a firm to strive for success. Due to these methods enterprises have a chance to achieve it. They do not give reliable directions whose fulfilment would guarantee success, but they provide business makers with valuable indications whose skillful realisation brings enterprises nearer to 'perfection'. However, one should not forget about other factors which shape the business's success. Sometimes, in spite of a good strategy and a properly conducted strategic analysis, an enterprise goes bankrupt. Why does it happen? Each entrepreneur who wants to achieve success has been asking himself this question. The risk which is taken all the time by entrepreneurs only occasionally brings the expected outcomes. If entrepreneurs take into consideration the results of strategic analysis, performed using for example the SWOT or the KSF method, then it is important for the analysis to be conducted as accurately and in as much detail as possible, since it may prove to be the key to achieving success by the enterprise. 


\section{Case study of selected enterprises}

\subsection{Nike - a Mystical Strategy - Dash for Success}

Nike has undeniably succeeded on the market and it certainly has succeeded in the field of pushing sports on the back burner. The story of Nike reveals the branding mechanisms and their ability to put everything in the shade. This concern virtually swallows cultural space and is a model super brand from the 1990s. "It shows the tendency, characteristic for branding, to blur the boundaries between the sponsor and the sponsored. Here is the producer of running shoes who set himself a goal of unseating professional sport, the Olympics, and even the famous sportsmen, in order for himself to become the only valid definition of sport". Nike's president, Phil Knight, dealt with shoes sale already in the $60 \mathrm{~s}$. However, he made his real fortune at the time when professional sports shoes had become an indispensible requisite of the 'jogging madness' which had embraced America. However, when the fashion changed in the middle $80 \mathrm{~s}$, other sports firms dominated the market. Nevertheless, Nike did not introduce a new type of sports shoes; they 'left' it to Adidas and Reebok. According to Knight Nike was to get transformed into "the best firm in the field of sports and fitness in the world" (Willigan, p. 94).

Nike was said to be a sportswear company established by a well-integrated gang of men who loved sports and deeply respected and admired great sportsmen. Actually, the process of establishment of the Nike company was much more complicated. "We may distinguish three basic guidelines by which Nike's executives were directed. The first one was the following: "Make stars out of a selected group of sportsmen stars in the Hollywood style, who would be associated not with their teams and sometimes not even with the discipline they cultivate but with some pure ideals pertaining to sport as such, like for example breaking down barriers or perseverance - in other words - with the ancient Greek and Roman ideal of the athletic virile body. The second was this: "Play Nike's 'Pure Sport' and its team of sports superstars against the obsessed with regulations, fossilised world of the traditional sport". And the third and the most important indication: "Stamp your logo everywhere as if your life depended on it" (Willigan, p. 94).

Nike decided to create a superstar. They used for this purpose the uncommon basketball skills of Michael Jordan, which elevated Nike to the peak of popularity, but, in spite of the fact that Jordan had already been famous, it were Nike's commercials which made him a global superstar. It is true that sportsmen like Muhammad Ali or Babe Ruth had enjoyed popularity already before the foundation of the Nike company, but none of them has reached such heights of popularity as Jordan has. "Sports stars from before Nike, irrespectively of however talented and worshipped they were, couldn't 'break off the ground' (Klein, p. 70).

The year 1985 was a landmark year in which sport got introduced to the world of entertainment. Nike's commercials with Michael Jordan's participation were simply delightful: freeze-frames, unusual close-ups, quick cuts, all that made Jordan look as if he could fly. 
"The idea of involving sports shoes production technology in the creation of a higher being Michael Jordan swimming in the air in slow motion - is an excellent example of a fairy-tale myth-creating method" (Klein, p. 70). Commercials with Jordan were the first video-clips, a total novelty. Jordan himself says: "Phil Knight and Nike have made a living dream out of me" (Klein, p. 70).

Nike has tried various ways to achieve the central position in professional sport. They even opened their own agency which was not only to represent sportsmen in the negotiations of the conditions of contracts, but also to create integrated marketing strategies for customers, complementing Nike's marketing strategy. As Knight once said "We do in sport - because sport is our field of activity" (Klein, 2014, p. 73). It was Knight's wish to set sport on a pedestal, which he has managed to do anyway. "In Nike Town on Manhattan, however, we will not see Michael Jordan or even basketball as a discipline of sport, but a revolving shoe. Like a prima donna, it draws the light of all the spotlights to itself - the first famous shoe in the world".

Nike Town is not only an ordinary shopping centre - the shops are almost temples which are the destination of pilgrimages of the faithful. "In Nike Town on East Fifty-seventh on Manhattan (...) wherever you look, swoosh is identified with sport in glass cabinets, in which the 'definition of sportsman' is presented with reverential care, in inspiring quotes on 'Courage', 'Honour', 'Victory' and 'Team Work', with which the parquet floor is encrusted, and on the inscription dedicating the building 'to all the sportsmen and their dreams'.

Nike is the king of super brands. Nike's icon resembles a stamp mark off - 'Nike's pipe'. That 'pipe' can be seen practically everywhere: in the company salons, on T-shirts, socks, underwear, beanies. Nike's employees tattoo their bodies with this icon to show their adherence to Nike. It is undoubtedly a reflection of the great role played by the Nike brand in the minds of its adherents.

Nike has indisputably achieved a stunning success. Sports superstars have been used by the firm to create its image. The synergy effect that Nike has achieved in their doings has exceeded the boldest expectations. The firm does not, however, intend to rest on their laurels. Nike bravely declares that "in the future Disney and not Reebok will be the firm's competitor". The plans are ambitious; however, the time will tell how the things will work out and how will 'Nike's pipe's' career develop (Klein, 2004, p. 72).

\subsection{Polish Cosmetics on Broadway - Inglot Ltd. - a Strategy of Internalisation - a Way to Success}

The firm Inglot came into being over 25 years ago in Przemyśl. It was set up by Wojciech Inglot, a chemistry studies graduate from the Jagiellonian University. He started to work in Polfa in Krakow, in the Research and Development Department. However, he dreamed of setting up his own business activity. The first product he made was a tape head cleaning fluid, the subsequent one - a deodorant stick. His stay in the USA during his studies had resulted in the idea of creating colourful cosmetics. The first product of this type was a nail polish. 
In 1994 Inglot entered into cooperation with the firm Kolmar which was one of the biggest concerns in the world dealing with the so-called contract manufacturing. At that time the Przemyslan company was producing cosmetics of many well-known brands, thus gaining access to new technologies. Thanks to that, Inglot's chemists had acquired the knowledge which was to make it possible for them to produce high quality cosmetics in the future. Five years later the cooperation with Kolmar ended and Wojciech Inglot decided to develop his own brand. In 2000 Inglot started to sell his own cosmetics in drugstores, where they were placed next to very renowned brands. As he didn't stand a good chance against the latter, he decided to introduce testers of his own cosmetics. In 2002 the first company salon was opened. It was an extremely innovatory action - Inglot's salon was the first one set exclusively to sell coloured cosmetics of a single producer. The president of the company argued that it was the only possible solution since he didn't stand a chance of being noticed in the toilet networks among lots of other brands. The small surface where he could be able to display his products would be insufficient to present his very rich offer. Besides, setting up his own stalls and salons Inglot was able to give up middlemen, which has considerably lowered the costs. However, Inglot is not only hundreds of colours of eye-shades, lipsticks, nail polishes and liners. In their offer they also have brushes and make-up applicators, artificial eyelashes, vanity bags, looking glasses and make-up remover wipes.

Around 95\% of all the products are made in Przemyśl. The remaining 5\% are e.g. eyeliners produced by the firm Faber Castel, glass packaging imported from Italy, and plastic packaging - from Taiwan (Burda, pp. 32-37).

Inglot's expansion overseas started with Canada. The owners of the shops with clothing accessories got interested in Inglot's island in Warszawa. In this way, in the end of March 2006 the first salon in Montreal got opened. That move triggered a chain reaction. Three months later another shop was opened on Malta. Inglot's Canadian shop was noticed by an Australian investor and that is how the international salons chain further developed. Wojciech Inglot grants a franchise to foreign investors; however, he also has his own salons. In July 2009 Inglot opened a salon in New York, on Broadway, at Time Square. The president of the Przemyśl company had wanted very much to open a shop in the USA and he eventually did. In February 2010 the Polish firm took part in the prestigious fair of make up: The Makeup Show in Los Angeles. Precisely during that fair Inglot got a very high note and the title of the firm's MAC competitor.

It is worth mentioning that Polish products are sold at considerably higher prices abroad than on the domestic market; however, they are regarded as specialist products there. In spite of the fact that their overseas prices are higher than their home prices, they are still considered reasonable in comparison to other brands of coloured cosmetics.

Grupa Kapitałowa Inglot consists of the production company Inglot Ltd. (a private limited company) and the company dealing with distribution, Inglot RSC Ltd. The incomes from sales have been rising since 2005, whereas the profit has clearly risen since 2006. It is not difficult to associate that year with the date of the beginning of internationalisation of the firm. It can be 
seen therefore that the company makes profits and its internationalisation does it good. Now the question should be asked what Wojciech Inglot did in order to win foreign markets. Firstly, he offered an interesting, eye-catching product. His colour palette is probably the widest among those available on the Polish market. However, in addition to colour, the cosmetics produced by the Przemyslan factory are characterised by high quality and a relatively reasonable price. A woman entering an Inglot's store is delighted with the range of colours accumulated in one place and the opportunity of free choice under the Freedom System, which is an innovative idea. An important advantage of Inglot's stores is the service - the staff focus on advising customers. There is also a possibility of a makeup test. The next positive feature is the spaciousness of stores and the fact that in some places they are combined with a beauty parlour. Besides, you can speak of Wojciech Inglot's good luck because the first offer of foreign cooperation appeared unexpectedly, following an incidental contact of the investor with the firm's island. It should be noted here, however, that the stand was attractive enough to draw the Canadian's attention. Here you cannot speak of 'luck' any more, but once again of a good product and a well-prepared distribution channel.

\subsection{Breitling - condemned to success - strategy of innovativeness, specialisation and quality}

Leon Breitling started his career with mounting mechanisms in one of the local workshops in Saint Imier. When he turned 24, he decided that it was high time he got independent and for this reason he opened a small watch making workshop. When by the end of the XXth century a new fashion - sports - prevailed in Europe, Breitling had already prepared a whole arsenal of stopwatches, which sold so well that soon his workshop in Saint Imier turned out too small (Richter, Schiffer, 2007).

Without thinking too long, he moved to the city of watchmakers: La Chaux-de-Fonds, where in 1892 he built a factory. Its official name was: Leon G. Breitling SA. Montbrillant Watch Manufactory and its special product were, naturally, clocks with stopwatches.

Leon Breitling's death coincided with the outbreak of World War I and his son, Gaston, took over the management of the firm. As a talented watchmaker he knew one thing for certain: a very attractive product was crucial. And he believed that watches which could tell the time with great accuracy were it. Therefore, he started experimenting with clock faces: he placed graduations on them facilitating various measurements e. g. of an average speed or distance. Success didn't take long to come: the army got interested in reliable chronographs by means of which they could synchronise to the second the time of an artillery bombardment with a simultaneously carried out infantry attack. And in these, frequently extreme conditions the wrist watches with stopwatches provided by the Breitling firm were perfectly working.

The reputation they had gained of a firm producing reliable watches turned out useful also in the times of peace. A clock with a stopwatch, patented at the beginning of the XXth century, bearing a promising name Vitesse (i.e. swiftness), became policemen's favourite toy. 
The graduation on the dial (from 15 to $150 \mathrm{~km} / \mathrm{h}$ ) helped establish the speed at which the first automobiles were moving. And they could develop the speed of up to even $30 \mathrm{~km} / \mathrm{h}$ at that time!

When after Gaston Breitling's sudden death the reins of the company were taken over by his almost 20-year old son, Willy, in Europe nothing else but civil aviation was being discussed. Willy knew that every plane had to have fail-safe clocks and it didn't take long for Breitling chronographs and deck clocks to appear on the dashboards of many planes. However, the biggest order was yet to come.

In 1937 Breitling created and patented a system of improvement of functionality and reliability of deck clocks. The reports of the new technology quickly reached the British Aviation Ministry. Shortly before the outbreak of World War II its representative contacted the Breitling firm and placed an order for a considerable number of deck clocks for the planes belonging to the Royal Air Forces. Breitling managed to promptly realise the commission and the clocks got to London still before the war.

In 1944 Breitling created a clock by means of which pilots could execute even very complex calculations of, among others, velocity, the distance covered and fuel consumption. Breitling timepieces were so well known that at the beginning of the 1950s they were already working on the dashboards of planes belonging to over 25 airlines.

In 1952, Breitling came up with a special model with a stopwatch which could very well be used as a navigation instrument. It was called Navitimer (from the words navigation and time) and it became pilots' iconic clock all over the world. Some elements of this model have remained unchanged until today and, the classic of its genre, it is still produced.

\section{Strategy of innovativeness, quality and specialisation}

Breitling is distinguished for its high specialisation in the field of timepieces for special purposes. Many revolutionary events, solutions and inventions may be noted in the history of the Firm. The most characteristic model and the one the most commonly associated with the brand is Navitimer, which is equipped with a navigational computer enabling a quick execution of all the calculations connected with air navigation.

The clocks from the Windrider series are the model respected by professionals. These models are able to resist the pressure of up to 30 bars, are shock resistant and equipped with a rotating ring, which is used to measure time underwater.

The series Professional is directed to the men who need something more than a usual watch in their everyday work. This collection includes, for example Aerospace, used by RAF pilots, or the Emergency model with a transmitter that allows you to call for help in extreme conditions, meant for pilots, soldiers and travellers. Two British guys whose helicopter once crashed over Antarctica got rescued thanks to the watch signal transmitted by Emergency.

The Aeromarine Line is addressed to professional divers. The Colt Ocean women's model, in turn, is diamond-studded and is referred to as the most sporty timepiece for ladies. A wonderful marriage of watch making and automotive art have resulted in the stylish Breitling- 
for-Bentlej collection. Both brands equal each other in prestige, elegance and the pursuit of top performance. Luxury models of this series are distinguished for their brave design and a thorough elaboration of the detail. All the mechanisms used in Breitling clocks undergo a very restrictive control and tests in the Swiss Institute for COSC Chronometers Testing.

At present, Breitling is a global leader in the production of mechanical timepieces. It is also the only clock brand in which each model of every collection has an official certificate of the timepieces tests issued by COSC. In 2009, on the occasion of 25th anniversary of the brand's existence, Calibre 01 was created - the only mechanism which is entirely produced and mounted in the Breitling manufacture. The annual production of Breitling clocks exceeds 150,000 pieces.

Undoubtedly, the strategy of innovativeness, specialisation and quality was the factor that has determined the success of the Breitling brand.

\section{Summary}

Success is an extremely complex process. It is not possible to determine a concrete list which will help us certainly achieve it, but the examination of factors and their analysis will make it possible to observe certain regularities which will be very helpful for enterprises. It will be possible to search out certain analogies, improve old theories and ideas or construe completely new ones on their basis. An important part in the elaboration of a winning strategy is played by the mission and vision. Obviously, it does not give any certainty that if the firm follows all the directions, it will achieve the desired success, but certainly it is a 'landmark' indicating how to proceed in order to avoid isolation and being removed from the market. Two strategic analyses, called SWOT Analysis and the Key Success Factors (KSF) Analysis, are very helpful here. They are the most popular and the most commonly applied methods in enterprises, and their appropriate use may contribute to the firm's success.

Running business activity is not a simple matter. Sometimes, in spite of a good, correctly conducted strategic analysis the firm does not succeed. Why is it so? Sometimes it is enough to find yourself in the right place at the right time, have wonderful ideas, a sense for business or simply a bit of luck to achieve success.

Success may be achieved consciously or through a chain of luckily coinciding events. Evidently, the firms which achieved their first successes without strategic planning had at their disposal the fortitude of their charismatic leaders. Other firms, e.g. Nike, bet on almost mystical elaboration of a foolproof strategy and its implementation brought the expected results.

The internationalisation of an enterprise and a good product may prove success-making factors. The cosmetic factory Inglot may be a good example here. The possession of a good and interesting product offer considerably facilitated the internationalisation process in its case. 
It is important for the product to attract customers, and it can also attract foreign investors, as it had place in the above mentioned case. It is, among others, thanks to the good features of the product and to the good distribution channel that Inglot has succeeded on foreign markets (Nieżurawski, Duarte, 2016).

Enterprises entering foreign markets must be able to adjust to the conditions found there. It calls for the modification not only of the products, but very often also of the manner of management of the whole business. Already today it is obvious that internationalisation is becoming part of strategy of a growing number of firms which have to put an enormous effort in its success.

Breitling Enterprise is a good example of implementation of the strategies of innovativeness, specialisation and quality which determined the success of the Swiss enterprise.

As can be concluded from the above examples, it is clear that there are people who are not afraid of risk and who infect others with their passion, stimulating them to act. It is they who create history, which may become a legend already tomorrow and on whose basis young people, inexperienced businessmen, will be building their own firms. Perhaps this is precisely the key to success. Mission, vision, strategy, strategic analyses, all those elements undeniably bring men of action nearer to success. However, we shouldn't limit ourselves to them; rather, giving all of ourselves, all our knowledge and commitment, we should reach for success with our own hands.

\section{References}

1. Akkermans, H., van Helden, K. (2002). Vicious and Virtuous Cycles in ERP Implementation: a Case Study of Interrelations between Critical Success Factors. European Journal of Information Systems, pp. 35-46.

2. Cardwell, G. (2008). The Influence of Enterprise Architecture and Process Hierarchies on Company Success. Total Quality Management, pp. 47-55.

3. De Vasconcellos, E. Sá, Sousa, J.A., Hambrick, D.C. (1989). Key Success Factors: Test of a General Theory in the Mature Industrial Product Sector. Strategic Management Journal, pp. 367-382.

4. Grant, R.M. (2016). Contemporary Strategy Analysis: Text and Cases Edition. John Wiley \& Sons, pp. 21-27.

5. Grunert, K.G., Ellegaard, Ch. (1992). The Concept of Key Success Factors: Theory and Method, pp. 2-25.

6. Hoffmann, W.H., Schlosser, R. (2001). Success Factors of Strategic Alliances in Small and Medium-sized Enterprises — an Empirical Survey. Long Range Planning, pp. 357-381. 
7. Islam, M.A. (2011). Effect of Entrepreneur and Firm Characteristics on the Business Success of Small and Medium Enterprises (SMEs) in Bangladesh. International Journal of Business and Management, p. 289.

8. Klein, N. (2004). No logo. Izabelin: Świat Literacki.

9. Lancaster, G., Massingham, L. (2010). Essentials of Marketing Management. Routledge, pp. 44-56.

10. Nieżurawski, L., Owczarczyk-Szpakowska, G. (2005). Strategic Management of the Enterprise (Zarządzanie strategiczne przedsiębiorstwem). Wyższa Szkoła HumanistycznoEkonomiczna, pp. 70-73.

11. Nieżurawski, L., Duarte, N., Nieżurawska, J. (2016). Determinanty sukcesu przedsiębiorstwa (studium przypadku wybranych przedsiębiorstw) [Success Determinants of Enterprises (Case study)]. Research Papers of the Wroctaw University of Economics/Prace Naukowe Uniwersytetu Ekonomicznego we Wrocławiu, 420, pp. 240-253.

12. Pahl, N., Richter, A. (2007). SWOT Analysis: Idea, Methodology and a Practical Approach. Grin Verlag.

13. Pickton, D.W., Wright, S. (1998). What's SWOT in Strategic Analysis? Strategic Change, pp. 101-109.

14. Pierścionek, Z. (2003). Competition and Business Development Strategies (Strategie konkurencji i rozwoju przedsiębiorstwa). Warszawa: PWN, pp. 81-82.

15. Porter, M.E. (2008). The Five Competitive Forces that Shape Strategy. Harvard Business Review, pp. 25-40.

16. Reh, F.J. (2005). Pareto's Principle - the 80-20 Rule. Business Credit-New York Then Columbia MD, p. 76.

17. Richter, B. (2007). The History of a Great Brand of Watches 1884 to the Present (Schiffer Book for Collectors). Schiffer.

18. Thompson, A.A., Strickland, A.J. (1996). Strategic Management. Concepts and Cases. Long Range Planning, pp. 907-908.

19. Umble, E.J., Haft, R.R., Umble, M.M. (2003). Enterprise Resource Planning: Implementation Procedures and Critical Success Factors. European Journal of Operational Research, pp. 241-257.

20. Valentin, E.K. (2001). SWOT Analysis from a Resource-based View. Journal of Marketing Theory and Practice, pp. 54-69.

21. Willigan, Willigan, High-Performance Marketing, http://hbr.org/1992/07/highperformance-marketing-an-interview-with-nikes-phil-knight/ar/1, 15.06.2019. 